\title{
Faktor-Faktor Yang Berhubungan Dengan Pola Asuh Anak Pada Keluarga Etnis Minang, Jawa Dan Batak \\ (Factors Associated With Family Parenting Children In Ethnic Minang, Javanese and Batak)
}

\author{
Maria Dewi Rahayu dan Siti Amanah
}

\author{
Departemen Sains Komunikasi dan Pengembangan Masyarakat, Fakultas Ekologi Manusia, \\ Institut Pertanian Bogor
}

\begin{abstract}
This research was conducted in the village of Sukajadi, District East Dumai, Kota Dumai, Riau Province. The study population is the entire family of ethnic Minang, Javanese and Batak residing in RT 21, 22 and 23 Sukajadi village. Respondents in this research were 100 families, consisting of 52 families of ethnic Minang, Javanese 14 families and 34 families of ethnic Batak. Analysis of relationships using Spearman Rank test and ANOVA. The results showed that the Minang ethnic family, factor role of mass media and communication patterns within the family is positively associated with parenting. Javanese family, physical environmental factors and the role of religious institutions that are positively associated with parenting. In the Batak ethnic family, social environment, media and communication patterns in families dealing with real positive parenting. The mass media and communication patterns within the family seem to have a relationship with the child's upbringing. This is because almost all respondents from both ethnic family Minang, Javanese and Batak who have access to the mass media, especially television which then affects the communication patterns within the family, especially between parents and children in the family.
\end{abstract}

Keywords: culture, communication,parenting

Abstrak

Penelitian ini dilakukan di Kelurahan Sukajadi, Kecamatan Dumai Timur,Kota Dumai, Provinsi Riau.Populasi penelitian adalah seluruh keluarga etnis Minang, Jawa dan Batak yang bertempat tinggal di RT 21 , 22 dan 23 Kelurahan Sukajadi.Responden dalam penelitian ini berjumlah 100 keluarga, yang terdiri dari 52 keluarga etnis Minang, 14 keluarga etnis Jawa dan 34 keluarga etnis Batak.Analisis hubungan menggunakan pengujian Rank Spearman dan Uji ANOVA.Hasil penelitian menunjukkan bahwa keluarga etnis Minang, faktor peran media massa dan pola komunikasi dalam keluarga paling berhubungan positif dengan pola asuh anak.Keluarga etnis Jawa, faktor lingkungan fisik dan peran lembaga keagamaan yang berhubungan positif dengan pola asuh anak. Pada keluarga etnis Batak, lingkungan sosial, media massa dan pola komunikasi dalam keluarga yangberhubungan nyata positif dengan pola asuh anak. Media massa dan pola komunikasi dalam keluarga terlihat memiliki hubungan dengan pola asuh anak. Hal ini disebabkan karena hampir seluruh responden baik dari keluarga etnis Minang, Jawa maupun Batak yang memiliki akses terhadap media massakhususnya televisi yang kemudian mempengaruhi pola komunikasi dalam keluarga khususnya antara orangtua dan anak dalam keluarga.

Kata kunci : budaya, komunikasi, pola asuh

\section{Pendahuluan}

Seorang anak di sebuah keluarga akan diasuh menurut nilai budaya danagama yang diyakini oleh kedua orangtuanya. Proses sosialisasi nilai budaya danagama tersebut dapat dilakukan melalui komunikasi verbal maupun komunikasinon verbal antara orangtua dan anak. Pikunas (1976) seperti yang dikutip oleh Hastuti (2008) mendefinisikan sosialisasi sebagai proses belajar untuk mengenali nilai-nilai dan ekspetansi kelompok, dan meningkatkan kemampuan untuk mengikutinya (conform) .Lingkungan tempat tinggal juga dapat mempengaruhi pola asuh yangditerapkan orangtua pada anak-anaknya. Situasi lingkungan tempat tinggal yangkondusif akan mendorong orangtua untuk memberikan 
pengasuhan yang baik bagi anak. Sebaliknya, lingkungan yang tidak kondusif cenderung orangtua tidak terlalu memperhatikan aspekaspek penting dalam pengasuhan. Pengaruh lingkungan sosial terhadap perkembangan anak mencakup faktor-faktor resiko dan faktor-faktor yang melindungi (protective and riskfactors). Faktor resiko merupakan variabel-variabel yang berhubungan secara signifikan terhadap kegagalan pertumbuhan seorang anak, sedangkan faktor yang melindungi adalah kondisi yang berhubungan positif terhadap keberhasilan perkembangan anak meskipun terjadi peningkatan faktor resiko yang harus dihadapi (Alfiasari, 2008, p.5)

Cole (1993) dalam Brooks (1997) seperti yang dikutip oleh Alfiasari(2008) mengidentifikasi faktor resiko yang secara umum menyebabkan kegagalan perkembangan seorang anak, yang mana dalam jangka pendek akan menyebabkanrendahnya tingkat kesehatan, kegagalan pertumbuhan, kegagalan perkembangan kognitif, dan juga kegagalan perkembangan sosial pada anak. Faktor resiko yang dimaksud antara lain (1) faktor ekologi yang mencakup lingkungan pertetanggan yang tidak nyaman dan aman, ketidakadilan yang muncul akibat perbedaan ras/suku/etnik, komunitas yang sebagian besar anggotanya adalah pengangguran,dan kemiskinan yang ekstrim yang terjadi dalam komunitas; (2) keadaan keluarga yang mencakup rendahnya kelas sosial, konflik keluarga, gangguan mental yangada dalam keluarga, jumlah anggota keluarga yang besar, rendahnya emotional bonding antara anak dan orangtua, perpecahan keluarga, dan adanya penyimpangan dalam komunikasi di dalam keluarga.

Merujuk pada konsep tersebut, lingkungan pemukimam kumuh (slum area) termasuk salah satu lingkungan tempat tinggal yang tidak kondusif bagipembentukan karakter anak.Hal ini ditunjukkan dengan kondisi sosial demografis di kawasan kumuh seperti kepadatan penduduk yang tinggi, kondisi lingkungan yang tidak layak huni dan tidak memenuhi syarat serta minimnya fasilitas pendidikan, kesehatan dan sarana prasarana sosial budaya. Tumbuhnya kawasankumuh terjadi karena tidak terbendungnya arus urbanisasi.

Salioso (2003) menyatakan bahwa Kota Dumai dirancang untuk menjadi "Pusat Pelayanan Industri dan Jasa di Pantai Timur Sumatera pada tahun 2020". Peluang ini tentunya tidak disia-siakan oleh para pencari kerja yang kemudian mencoba peruntungannya dengan melakukan migrasi ke Kota Dumai.Data dari Badan Pusat Statistik Provinsi Riau tahun 2007 menunjukkan bahwa penduduk Kota Dumai berjumlah 231.121 jiwa. Meningkatnya jumlah pendatang ke Kota Dumai dapat membawa dampak pada munculnya kawasan pemukiman kumuh (slum area). Data dari Bappeda Kota Dumai pada tahun 2000 menunjukkan bahwa dari 32 kelurahan yang ada di Kota Dumai kawasan kumuh terdapat di 2 kecamatan yaitu Kecamatan Dumai Barat (Kelurahan Pangkalan Sesai dan Kelurahan Rimba Sekampung) dan Dumai Timur (Keluarahan Teluk Binjai dan Kelurahan Sukajadi). Penduduk yang bermukim di kawasan tersebut rata-rata bekerja di sektor informal.Tata letak bangunan di kawasan tersebut tidak teratur, kepadatan penduduk sedang hingga tinggi, kerapatan bangunan sedang hingga tinggi, fasilitas dan sarana umum kurang memadai, dan rawan bencana terutama banjir, kebakaran dan penyakit.Kawasan pemukiman kumuh tersebut hingga saat ini masih ditemui di Kota Dumai. Atas dasar itulah, maka diteliti pola asuh anak dalam keluarga etnis Minang, Jawa dan Batak yang tinggal di Kelurahan Sukajadi.Kelurahan ini berbatasan langsung dengan daerah bantaran sungai Dumai. Berdasarkan uraian di atas tujuan penelitian ini adalah menganalisa faktor-faktor yang berhubungan dengan pola asuh anak pada keluarga etnis minang, jawa dan batak. 


\section{Metode Penelitian}

Penelitian ini menggunakan pendekatan deskriptif analitis, dengan menggunakan analisis data secara kuantitatif dan kualitatif. Pendekatan kuantitatif yang digunakan adalah pendekatan kuantitatif non eksperimen yaitu penelitian yang tidak melakukan manipulasi dan kontrol dalam arti subjek diobservasi apa adanya kemudian hubungan antar variabel diuji tanpa mengadakan perubahan apapun (Handayani dan Sugiarti, 2002). Penelitian ini dilakukan di Kelurahan Sukajadi, Kecamatan Dumai Timur, Kota Dumai, Provinsi Riau, khususnya RT 21, RT 22 dan RT 23.Penelitian dilakukan selama bulan Mei sampai Juni 2009. Penelitian ini akan dilakukan pada responden yang beretnis Minang (mewakili sistem kekerabatan Matrilineal), Jawa (mewakili sistem kekerabatan Bilateral), dan Batak (mewakili sistem kekerabatan Patrilineal). Penduduk migran yang beretnis Minang mayoritas bermukim di RT 21.Penduduk beretnis Minang cenderung tersebar merata di seluruh RT di Kelurahan Sukajadi, namun penelitian ini mengambil sampel penduduk beretnis Minang di RT 21.Penduduk migran etnis Jawa mayoritas bermukim di RT 22.Penduduk migran yang beretnis Batak mayoritas bermukim di RT 23. Penelitian ini menggunakan stratified random sampling dimana responden dikelompokkan menurut etnisnya dan dari setiap etnis akan diambil responden dengan menggunakan rumus Slovin dengan nilai kritis sebesar $10 \%$.

\section{Hasil dan Pembahasan Karakteristik Responden Penelitian}

Responden dalam penelitian ini adalah penduduk Kelurahan Sukajadi RT21, RT 22 dan RT 23.Penduduk RT 21 mewakili keluarga etnis Minang, RT 22 mewakili keluarga etnis Jawa dan RT 23 mewakili keluarga etnis Batak. Sebaran responden etnis
Minang, Jawa dan Batak berdasarkan usia menunjukkan bahwa bahwa sebaran terbesar untuk kepala keluarga dari keluarga etnis Minang berada pada rentang usia antara 40-49 tahun. Berbeda halnya dengan sebaran terbesar untuk kepala keluarga dari keluarga etnis Jawa dan Batak yang berada pada rentang usia antara 30-39 tahun.

Rata-rata tingkat pendidikan formal dari Kepala Keluarga pada keluarga etnis Minang, Jawa dan Batak adalah tamat SMA/sederajat. Kepala keluarga yang pendidikan formal terakhirnya adalah Diploma 3 ditemukan pada etnis Minang sebanyak 2\% dan Batak sebanyak 6\%. Kepala keluarga dengan pendidikan formal terakhir S1 hanya ditemukan pada keluarga etnis Minang.Pada keluarga etnis Jawa, masih ditemukan 14\% kepala keluarga yang pendidikan formal terakhirnya hanya tamat SD/sederajat. Menurut wawancara mendalam, mereka hanya menamatkan Sekolah Dasar karena kendala biaya dalam keluarga dan pola pikir orangtua mereka yang cenderung menganggap pendidikan tidak begitu penting.Pendidikan non formal seperti kursus ataupun pelatihan, tidak banyak diikuti oleh Kepala Keluarga (KK) dari keluarga yang menjadi responden dalam penelitian ini.Pendidikan non formal seperti itu cenderung diikuti oleh istri, namun tidak banyak yang menggunakan ketrampilan yang mereka peroleh melalui pendidikan non formal tersebut.

Seluruh responden dalam penelitian ini bekerja di sektor non pertanian. Pekerjaan tersebut antara lain meliputi wiraswasta, karyawan swasta, pedagang, Pegawai Negeri Sipil (PNS), buruh pabrik, buruh bangunan, dan tukang becak. Mereka tidak menggeluti jenis pekerjaan di sektor pertanian mengingat bahwa di kawasan Kelurahan Sukajadi tidak banyak ditemukan lahan pertanian.Hampir seluruh lahan kosong yang ada di Kelurahan Sukajadi digunakan untuk membangun fasilitas pertokoan, pasar, klinik, dan kawasan perkantoran. Hal ini menunjukkan bahwa 
terdapat konversi lahan pertanian menjadi lahan non pertanian di Kelurahan Sukajadi.

Pengeluaran keluarga etnis Minang untuk memenuhi kebutuhan pangan paling besar berada pada kisaran Rp 700.000,00 - Rp 900.000,00. Pada keluarga etnis Jawa dan Batak, pengeluaran untuk memenuhi kebutuhan pangan berada pada kisaran $\mathrm{Rp}$ $700.000,00$ - Rp 900.000,00 dan Rp 900.000,00 - Rp 1.100.000,00, dengan jumlah persentase yang sama yakni $43 \%$ untuk keluarga etnis Jawa dan 47\% untuk keluarga etnis Batak. Pengeluaran untuk memenuhi kebutuhan pangan ini sudah mencakup kebutuhan pangan pokok dan non pokok selama sebulan dalam keluarga tersebut.

Pengeluaran untuk memenuhi kebutuhan non pangan mencakup kebutuhan sandang, biaya pendidikan anak, biaya kesehatan, hiburan, tabungan dan membayar tagihan sewa rumah, listrik serta air persentase terbesar pengeluaran untuk memenuhi kebutuhan non pangan pada keluarga etnis Minang dan Batak berada pada kisaran Rp 400.000,00 - Rp 600.000,00 per bulan. Pada keluarga etnis Jawa, persentase terbesar pengeluaran untuk memenuhi kebutuhan non pangan berada pada kisaran Rp 200.000,00 Rp 400.000,00.Bagi keluarga etnis Minang dan Jawa, pengeluaran non pangan paling banyak dialokasikan untuk biaya sekolah anak dan membayar tagihan sewa rumah, listik dan air. Berbeda dengan keluarga etnis Jawa yang masih mengalokasikan pendapatannya untuk ditabung meskipun tidak selalu sama jumlahnya setiap bulan. Hal ini berhubungan dengan responden dari keluarga etnis Jawa yang persentase kepemilikan rumahnya lebih besar dibanding keluarga etnis Minang dan Batak sehingga tidak perlu mengalokasikan pendapatan untuk membayar sewa rumah melainkan hanya membayar tagihan listrik dan air. Hiburan bukan merupakan suatu prioritas bagi keluarga etnis Minang, Jawa dan Batak.Menurut mereka, pemenuhan kebutuhan hiburan sudah cukup dengan menonton televisi di rumah.Hal ini juga didukung dengan kepemilikan parabola hampir di setiap rumah yang menjadi responden dalam penelitian ini.

Rasio kepemilikan aset berupa rumah, tanah, ternak, kendaraan bermotordan perhiasan pada keluarga etnis Minang, Jawa dan Batak menunjukkan bahwa keluarga etnis Batak memiliki semua asset yang disebutkan.Hampir seluruh responden baik dari keluarga etnis Minang, Jawa maupun Batak memiliki kendaraan bermotor, bahkan terdapat beberapa keluarga yang memiliki kendaraan bermotor lebih dari satu.Hal ini menunjukkan bahwa kendaraan bermotor merupakan aset yang penting bagi keluarga karena dibutuhkan untuk keperluan mobilitas.

Berkaitan dengan rasio kepemilikan aset berupa rumah, keluarga etnisJawa lebih banyak yang memiliki rumah sendiri dibanding keluarga etnis Minang dan Batak yang mayoritas masih menempati rumah sewa.Hal ini juga berkaitan dengan jumlah pengeluaran non pangan dari keluarga etnis Jawa yang tidak terlalu banyak dialokasikan untuk membayar sewa rumah.Jenis aset berupa tanah dimiliki oleh keluarga etnis Minang dan Batak.Tanah yang dimiliki berupa kebun kelapa sawit yang letaknya jauh dari tempat tinggal mereka. Pemeliharaan asset tersebut biasanya tidak dilakukan langsung oleh pemilik, melainkan dengan menggaji orang lain untuk menjaga dan merawat kebun tersebut. Pemilik hanya datang untuk meninjau kira-kira dua kali sebulan.

Jenis aset berupa ternak hanya dimiliki oleh beberapa keluarga etnis Batak.Jenis ternak yang dipelihara adalah babi.Sama halnya dengan kebun kelapa sawit, pemeliharaan ternak juga tidak dilakukan langsung oleh pemilik.Pemilik biasanya memantau sekali dalam seminggu karena letak tampat pemeliharaan yang tidak begitu jauh dari tempat tinggal pemilik.Rasio kepemilikan aset berupa perhiasaan paling banyak dimiliki oleh keluarga etnis Batak.Menurut hasil 
wawancara, kepemilikan aset berupa kebun, ternak dan perhiasaan merupakan bentuk investasi jangka panjang dari keluarga migran ini.

Makanan pokok dari seluruh responden adalah nasi.Pola makan yang diamati adalah mencakup frekuensi makan per hari, frekuensi konsumsi daging per minggu, frekuensi konsumsi ikan per minggu dan frekuensi konsumsi telur per minggu.keluarga etnis Jawa dan Batak mayoritas makan tiga kali sehari. Keluarga etnis Minang lebih banyak yang makan dengan frekuensi dua kali sehari.Pada keluarga yang frekuensi makannya dua kali sehari, biasanya yang dilewatkan adalah sarapan pagi.Hal ini terjadi karena mereka tidak terbiasa sarapan pagi.Jika istri bekerja, maka pada pagi hari istri biasanya hanya menyiapkan bekal untuk dibawa anak ke sekolah.Jika tidak, maka anak terbiasa sarapan di sekolah.

Keluarga etnis Minang paling sering mengkonsumsi telur dan ikan dalam seminggu.Frekuensi konsumsi daging hanya satu kali seminggu dan lebih bersifat tidak menentu.Menurut wawancara, mereka hanya mengkonsumsi daging saat ada perayaan keagamaan seperti Lebaran dan Idul Adha serta jika ada acara keluarga di rumah.Mereka tidak menganggap daging sebagai pangan yang wajib dikonsumsi setiap minggunya.Ikan dan telur lebih sering dikonsumsi karena harganya yang lebih murah dibandingkan dengan daging.

Keluarga etnis Jawa juga lebih sering mengkonsumsi ikan dan telur dibandingkan daging dalam seminggu. Sama halnya dengan keluarga etnis Minang, menurut keluarga etnis Jawa, mereka hanya mengkonsumsi daging saat Lebaran, Idul Adha, ataupun saat ada acara keluarga di rumah. Harga daging yang mahal menjadi pertimbangan bagi mereka untuk tidak sering mengkonsumsi daging.

Lebih dari setengah dari jumlah responden keluarga etnis Batak mengkonsumsi daging satu kali seminggu.
Seluruh responden keluarga etnis Batak juga mengkonsumsi ikan dan telur lebih dari atau sama dengan tiga kali seminggu. Hal ini berhubungan dengan jumlah pengeluaran keluarga etnis Batak untuk memenuhi kebutuhan pangan yaitu berkisar antara $\mathrm{Rp}$ 700.000,00 - Rp 900.000,00 dan Rp $900.000,00$ - Rp 1.100.000,00. Frekuensi Makan/minggu

\section{Keluarga Etnis Minang}

$\begin{array}{rlr}\text { Etnis } & \text { Minang menganut } & \text { sistem } \\ \text { kekerabatan } & \text { matrilineal dimana garis }\end{array}$ keturunan mengikuti garis keturunan ibu.Pada responden keluarga migran etnis Minang, terlihat bahwa pola asuh anak yang diterapkan tidak berbeda antara anak laki-laki dan anak perempuan. Anak laki-laki dan anak perempuan menerima pengasuhan yang sama satu sama lain.Menurut hasil wawancara dengan responden, pembedaan hanya ditemukan dalam bentuk pemberian pakaian dan mainan.Selebihnya, responden mengaku tidak membedakan pengasuhan antara anak laki-laki dan anak perempuan.

Berdasarkan hasil uji korelasi menggunakan Rank Spearman, korelasiyang signifikan terlihat antara pola komunikasi dalam keluarga dengan penggunaan mediamassa dalam keluarga tersebut dengan koefisien korelasi sebesar 0,277. Hal ini menunjukkan bahwa pola asuh anak dalam keluarga etnis Minang sedikit banyak berhubungan dengan pola komunikasi dan penggunaan media massa dalam keluarga tersebut.

Keluarga etnis Minang menggunakan media massa untuk kepentinganhiburan dan pendidikan. Hampir setiap keluarga yang menjadi responden memiliki fasilitas hiburan yang memadai. Frekuensi menonton per hari rata-rata adalah 8,6 jam. Pola komunikasi dalam keluarga etnis Minang juga dipengaruhi oleh frekuensi penggunaan media televisi oleh anggota keluarga. Menurut wawancara 
mendalam dengan salah satu responden dari keluarga etnis Minang, terlihat bahwa penggunaan media massa dalam keluarga sangat berpengaruh terhadap pola komunikasi dalam keluarga khususnya antara anak dan orangtua.

"Anak-anak kalau nonton TV cepet banget nangkep, Mbak.. Apalagi niru gaya ngomongnya yang di TV itu.. Kalau saya ingetin udah pinter ngejawab..Film kartun jaman sekarang juga udah banyak adegan berantemnya segala.. Pusing juga ngadepinnya.." (Ibu Mariam, RT 21)

Hal ini menunjukkan bahwa kontrol orangtua dalam mengawasi tontonan anak masih kurang. Anak dengan mudah dapat membentuk sendiri persepsi mengenai mana yang baik dan tidak baik melalui segala informasi yang didapat melalui televisi tanpa adanya filterisasi dari orangtua.Hal ini kemudian dapat berdampak pada perilaku anak di lingkungan sosialnya. Sa'adiyah (1998) dalam penelitiannya pada keluarga etnis Jawa dan Minang yang tinggal di desa dan kota menyatakan bahwa anak yang tinggal di kota lebih banyak menerima stimulasi dari orangtuanya dibandingkan dengan anak yang tinggal di desa. Hal tersebut dipengaruhi oleh nomor urut anak dalam keluarga, pendidikan orangtua dan pendapatan keluarga.Pada kasus ini, keluargamigran etnis Minang tinggal di kawasan perkotaan yang telah modern dan memiliki akses bebas terhadap teknologi.Hal ini seharusnya memberi pengaruh baik dalam hal pemberian stimulasi pada anak.Tingkat pendidikan orangtua yang rata-rata hanya tamat SMA/sederajat dapat mempengaruhi pola pikir mereka dalam hal pengasuhan anak. Mereka beranggapan bahwa pengasuhan hanya semata bersifat fisik dan kurang memperhatikan kebutuhan anak akan stimulasi positif yang dapat memaksimalkan pertumbuhan dan perkembangan mereka.
Jumlah anak dan nomor urut anak dalam keluarga juga mempengaruhi pengasuhan yang diberikan orangtua pada anak. Pada responden keluarga etnis Minang yang tergolong keluarga kecil, anak masih memperoleh perhatian penuh dari kedua orangtuanya. Berbeda dengan keluarga etnis Minang yang tergolong keluarga besar dengan jumlah anak yang banyak. Perhatian orangtua tidak lagi sepenuhnya diterima oleh anak karena orangtua mempunyai tanggung jawab besar untuk memenuhi kebutuhan hidup keluarga. Usia anak juga mempengaruhi pengasuhan yang diberikan orangtua. Jika usia anak telah dirasa cukup dewasa maka orangtua tidak lagi mengawasi dan memperhatikan anak seperti saat anak masih kecil. Anak dibiarkan melakukan apa yang diinginkan dan hanya diawasi sesekali oleh orangtua. Hal ini menunjukkan bahwa hubungan antara anak yang telah beranjak dewasa dengan orangtuanya tidak sedekat hubungan saat anak masih kecil dan berada dalam pengawasan orangtua sepenuhnya.

"Ya..sekarang kan udah gede-gede anak saya, Mbak.. Gak perlulah diawasi terus, ditanyain mau kemana, ngapain.. Yang penting dia gak macem-macem di luarsana..(Ibu Saidah, RT 21)

Berdasarkan hasil korelasi Rank Spearman juga terlihat bahwa lingkunganfisik, lingkungan sosial, peran sekolah, peran keluarga besar dan peran media massa tidak berhubungan positif dengan penanaman nilai Keadilan dan Kesetaraan Gender (KKG) dan fungsi prokeasi dalam keluarga. Lingkungan fisik yang kurang memadai, lingkungan sosial atau pergaulan di kawasan pemukiman yang tidak kondusif, dan akses terhadap media massakhususnya televisi yang mudah, tidak mendukung terciptanya iklim pengasuhan yang baik bagi anak.

Peran sekolah dirasa kurang mendukung terbentuknya karakter anak.Halini dapat dilihat melalui kutipan wawancara 
dengan salah satu responden darikeluarga etnis Minang.

”Sekolah ya gitu aja lah, Mbak. Paling ngasih PR, itu juga jarang kayaknya..Sekolahnya juga sekolah negeri, jadi guru-gurunya kayaknya juga kurang merhatiin anak muridnya.. Yang penting ngasih PR, ada ulangan, ada ujian.."(Bapak Rahmat, RT 21)

Kehadiran anggota keluarga besar dalam keluarga etnis Minang dirasasangat membantu dalam hal meringankan pekerjaan rumah tangga. Hanya 4 responden keluarga dari total 52 responden keluarga etnis Minang yang menyatakan bahwa anggota keluarga besar yang ikut tinggal bersama mereka juga turut membantu dalam hal finansial.Adanya anggota keluarga besar yang ikut tinggal bersama juga tidak begitu membantu dalam hal pengasuhan anak secara psikis.

"Mertua saya kan tinggal sama kami, Mbak..Ya, kalau saya lagi jualan anak saya Ibu yang jaga. Kadang Ibu sambil masak juga.. Daripada anak saya bawa jualan ke pasar kan ntar malah repot.. Jadi di rumah saja, ada yang jagain ini"'(Ibu Rani, RT21)

\section{Keluarga Etnis Jawa}

Etnis Jawa menganut sistem yang bersifat bilateral. Keluarga cenderung menganggap anak laki-laki dan anak perempuan adalah sama. White (1975) seperti yang dikutip dalam Zeitlin, Megawangi, Kramer, Colleta, Babatunde dan Garman (1995) menyatakan bahwa pada keluarga petani Jawa dalam desa yang miskin, anak yang masih kecil juga terlibat secara aktif dalam pekerjaan rumah tangga, menjaga saudara kandungnya dan beberapa pekerjaan dalam hal pertanian. Koentjaraningrat (1985) dalam Zeitlin, Megawangi, Kramer, Colleta,
Babatunde dan Garman (1995) juga menyatakan bahwa bagi keluarga Jawa yang tergolong miskin, anak merupakan aset untuk memberikan kontribusi bagi pendapatan keluarga. Berbeda dengan keluarga Jawa yang tergolong ekonomi menengah ke atas yang menganggap anak sebagai prestise.

Responden keluarga migran etnis Jawa pada penelitian ini rata-rata tergolong keluarga kecil. Hanya 2 dari 14 responden yang tinggal bersama dengan anggota keluarga besarnya. Hal ini juga terlihat dari korelasi Rank Spearman yang menunjukkan bahwa peran keluarga besar tidak berhubungan positif dengan penanaman nilai Keadilan dan Kesetaraan Gender (KKG) dan fungsi prokreasi dalam keluarga migran etnis Jawa.Kehadiran anggota keluarga besar dalam keluarga responden hanya memberi pengaruh dalam meringankan pekerjaan rumah tangga dan membantu menjaga anak, tidak memberi pengaruh dalam hal finansial keluarga. Korelasi antara lingkungan fisik dan peran lembaga keagamaan adalah yang paling signifikan diantara faktor-faktor lainnya.Hal ini ditunjukkan dengan kegiatan keagamaan yang aktif dilaksanakan dan diikuti oleh penduduk di lingkungan RT 22.Pengajian diadakan setiap hari Rabu dan anak-anak juga aktif mengikuti pelajaran mengaji.Menurut salah satu responden, kegiatan belajar mengaji bagi anak-anak cukup memberi pengaruh dalam hal sikap dan tingkah laku anak seharihari.Anak menjadi lebih rajin sholat, pintar mengaji dan menjadilebih penurut pada orangtua.Hal ini juga mendukung pernyataan Koentjaraningrat yang menyatakan bahwa masyarakat Jawa adalah masyarakat yang sangat berpegang pada nilai agama (Zeitlin, Megawangi, Kramer, Colleta, Babatunde dan Garman, 1995).

"Kalau yang besar saya suruh ikut ngaji, Mbak.. Biasanya seminggu empat kalo dia belajar ngaji sama guru ngajinya. Biar ada bekal ilmu 
agamanya lah dari kecil..(Ibu Susi, RT 22)

Murder (1978) dalam Zeitlin, Megawangi, Kramer, Colleta, Babatundedan Garman (1995) menyatakan bahwa budaya Jawa termasuk salah satu budaya kolektivisme yang salah satunya diwujudkan dalam bentuk gotong royong.Hal ini sudah tidak ditemukan lagi dalam kehidupan keluarga etnis Jawa di Kelurahan Sukajadi.Hal ini disebabkan karena semakin memudarnya nilai kebudayaan Jawa yang ada dan faktor pekerjaan yang menyita waktu masing-masing responden dari keluarga migran etnis Jawa.

Peran media massa terbukti signifikan tidak memiliki hubungan yang bersifat positif dengan fungsi prokreasi dalam keluarga etnis Jawa. Padahal terdapat 10 dari 14 orangtua yang mengaku sering menonton televisi bersama anak.Meskipun demikian, orangtua jarang menggunakan kesempatan menonton televisi bersama anak untuk menanamkan nilai moral pada anak.Menonton televisi hanya dianggap sebagai sarana hiburan bagi keluarga.Hal ini juga berhubungan dengan tingkat pendidikan formal Kepala Keluarga (KK) dari keluarga migran etnis Jawa yang rata-rata hanya tamat $\mathrm{SMA} /$ sederajat, bahkan ada yang hanya menamatkan SD/sederajat.

\section{Keluarga Etnis Batak}

Etnis Batak menganut sistem kekerabatan yang bersifat patrilineal (mengikuti garis keturunan ayah).Pada keluarga etnis Batak, anak laki-laki adalah penting karena merupakan penerus marga.Seorang anak laki-laki dalam keluarga Batak memiliki tanggung jawab untuk bisa meneruskan keturunan sehingga dituntut untuk hidup mandiri dan bertanggungjawab.

Berdasarkan uji korelasi dengan menggunakan Rank Sperman, beberapafaktor yang memiliki hubungan yang sangat signifikan (pada level 0,01) adalah hubungan antara lingkungan fisik dengan lingkungan sosial, media massa dan pola komunikasi keluarga. Korelasi positif antara lingkungan fisik dengan lingkungan sosial dapat dilihat dari anak-anak dari keluarga etnis Batak yang lebih sering bermain di luar rumah dan berbaur dengan lingkungan sekitar tempat tinggal mereka. Orangtua dari keluarga etnis Batak juga sering berinteraksi dengan tetangga dan membicarakan topik yang berkaitan dengan kehidupan keluarga maupun topik lain yang bersifat umum.

Korelasi positif antara lingkungan fisik dengan media massa terlihat dariketerdedahan keluarga etnis Batak terhadap teknologi. Semua keluarga etnis Batak yang menjadi responden memiliki televisi dan parabola di rumah masingmasing dengan rata-rata frekuensi menonton televisi sebanyak 8,6 jam per hari. Hal ini menunjukkan bahwa hiburan adalah kebutuhan mutlak bagi keluarga etnis Batak.Lingkungan sosial berhubungan signifikan pada level 0,01 dengan peran keluarga besar dan pola komunikasi dalam keluarga. Keluarga etnis Batak dalam penelitian ini tergolong aktif dalam mengikuti kegiatan di lingkungan sosial baik di sekitar tempat tinggal maupun di lingkup gereja, mesjid atau tempat kerja.Mereka juga cenderung melibatkan sanak saudara dalam aktivitas kehidupan mereka.Hal ini membuat mereka memiliki kemampuan bersosialisasi yang cukup baik dengan lingkungan sekitar.

Mayoritas responden dari keluarga etnis Batak adalah beragama Kristen Protestan. Mereka cenderung menyekolahkan anak-anak mereka ke sekolah swasta. Alasan mereka memilih sekolah swasta adalah agar anak-anak mereka dapat lebih diperhatikan perkembangan kognitif, afektif maupun motoriknya dibandingkan jika sekolah di sekolah negeri. Lembaga keagamaan dan keluarga besar tidak begitu berperan dalam penanaman nilai Keadilan dan Kesetaraan Gender (KKG) pada keluarga migran etnis Batak. Hanya terdapat 5 keluarga dari 34 
keluarga etnis Batak yang tinggal bersama dengan anggota keluarga besar. Kegiatan keagamaan yang diikuti oleh keluarga etnis Batak, khususnya yang beragama Kristen Protestan juga tidak terlalu menitikberatkan pada penanaman nilai keadilan dan kesetaraan gender, sehingga lembaga keagamaan tidak begitu berperan dalam penanaman nilai Keadilan dan Kesetaraan Gender (KKG).

Sebaliknya, peran lembaga keagamaan terlihat berhubungan positif denganfungsi prokreasi dalam keluarga etnis Batak.Hal ini disebabkan oleh ajaran agama masing-masing responden yang menitikberatkan pada penanaman nilai moral.Pola komunikasi dalam keluarga juga memiliki hubungan positif dengan fungsi prokreasi keluarga etnis Batak.Pola komunikasi yang terbentuk dalam responden keluarga etnis Batak cenderung bersifat komunikasi dua arah sehingga melalui pola komunikasi yang demikian orangtua dapat menanamkan nilai moral dan budaya kepada anak tanpa membuat anak merasa digurui.

\section{Kesimpulan}

Faktor peran media massa dan pola komunikasi dalam keluarga paling berhubungan positif dengan pola asuh anak. Pada keluarga etnis Jawa, faktor lingkungan fisik dan peran lembaga keagamaan yang berhubungan positif dengan pola asuh anak. Pada keluarga etnis Batak, lingkungan sosial, media massa dan pola komunikasi dalam keluarga yang berhubungan nyata positif dengan pola asuh anak. Media massa dan pola komunikasi dalam keluarga terlihat memiliki hubungan dengan pola asuh anak. Hal ini disebabkan karena hampir seluruh responden baik dari keluarga etnis Minang, Jawa maupun Batak yang memiliki akses terhadap media massa khususnya televisi yang kemudian mempengaruhi pola komunikasi dalam keluarga khususnya antara orangtua dan anak.

\section{Daftar Pustaka}

Hastuti, Dwi. 2008. Pengasuhan: Teori, Prinsip dan Aplikasinya. Bogor: Departemen Ilmu Keluarga dan Konsumen, Fakultas Ekologi Manusia, Institut Pertanian Bogor.

Alfiasari. 2008. Pengasuhan: Peran Strategis Orangtua dan Komunitas. Bogor. Departemen Ilmu Keluarga dan Konsumen, Fakultas Ekologi Manusia, Institut Pertanian Bogor.

Salioso, Herdi. 2003. Kota Dumai Mutiara Pantai Timur Sumatera. Pekanbaru: UNRI Press.

Handayani, Trisakti dan Sugiarti. 2002. Konsep dan Teknik Penelitian Gender. Malang: UMM Press.

Sa'adiyyah, Nino Yayah. 1998. Pengaruh Karakteristik Keluarga dan Pola Pengasuhan Terhadap Pertumbuhan dan Perkembangan Anak (Studi Kasus pada Etnis Jawa dan Minang) [Tesis]. Bogor: Departemen GiziMasyarakat dan Sumber Daya Keluarga, Fakultas Pertanian, InstitutPertanian Bogor.

Zeitlin, Marian F, Ratna Megawangi, Ellen F.Kramer, Nancy D.Colleta, E.D Babatunde dan David Garman, 1995. Strengthening the Family:Introduction for International Development. New York: United Nations University Press. 